\title{
Characteristics of chlamydia-like organisms pathogenic to fish
}

\author{
Malgorzata Pawlikowska-Warych ${ }^{1} \cdot$ Wieslaw Deptula $^{1}$
}

Received: 27 March 2015 /Revised: 11 June 2015 / Accepted: 22 June 2015 / Published online: 10 July 2015

(C) The Author(s) 2015. This article is published with open access at Springerlink.com

\begin{abstract}
Bacteria from the Chlamydiales order have been long known, especially as pathogenic bacteria to humans and many animal species, principally including birds and mammals. But for slightly over 20 years, they have been identified in the aquatic environment as endosymbionts of amoebas and sea worms. For several years, they have also been recorded as a cause of diseases among fish, causing respiratory system infections in the form of epitheliocystis of the gill. At present, 11 chlamydia-like organisms pathogenic to fish have been described, including nine new ones, classified into six families, four of which are already known (Parachlamydiaceae, Rhabdochlamydiaceae, Candidatus Parilichlamydiaceae, Candidatus Clavichlamydiaceae) and two newly created families, namely Candidatus Actinochlamydiaceae and Candidatus Parilichlamydiaceae. This paper characterises 11 chlamydialike organisms, as well as seven isolates not classified into families, which are pathogenic to fish, presenting their genetical properties allowing for their classification, as well as morphological properties and diseases caused.
\end{abstract}

Keywords Fish · Chlamydia-like organisms - Epitheliocystis

\section{Introduction}

Diseases among fish are caused by many pathogens, including bacteria (Mitchell and Rodger 2011; Joh et al. 2013), viruses

Communicated by: Agnieszka Szalewska-Palasz

Małgorzata Pawlikowska-Warych

pawlikowska.sz@home.pl

1 Department of Microbiology, Faculty of Biology, University of Szczecin, Felczaka 3c, 71-412 Szczecin, Poland
(Pierce and Stepien 2012), fungi (Rodriguez-Tovar et al. 2011; Steckler et al. 2014; Yu et al. 2014) and parasites (Mansell et al. 2005; Steinum et al. 2010; Mitchell and Rodger 2011; Karlsbakk et al. 2013). Among bacterial pathogens, the most frequently listed include Aeromonas salmonicida (DallaireDufresne et al. 2014), Flavobacterium sp. (Zamora et al. 2013), Vibrio alginolyticus (Samad et al. 2014), as well as microbes recognised as zoonotic pathogens, such as Vibrio vulnificus, Edwardsiella tarda, Streptococcus iniae, Mycobacterium marinum (Haenen et al. 2013), as well as Citrobacter freundii and Aeromonas hydrophila (Joh et al. 2013). Also, recently, as one of the causes of bacterial diseases in fish indicated bacteria from the Chlamydiales order, Candidatus Piscichlamydiaceae and Candidatus Clavichlamydiaceae (Table 1), which contribute to skin and gill epithelial cysts, so-called epitheliocystis (Nowak and LaPatra 2006; Stride et al. 2014). It must be added that the contribution of bacteria from the Chlamydiales order, as the cause for fish diseases, was doubted due to prior lack of association between those pathogens and the aquatic environment. In recent years, however, it has been proved that new species have been described among those bacteria, named chlamydia-like organisms (CLOs), which are generally found in the aquatic environment, including as endosymbionts of amoebas (Corsaro and Venditti 2009) and sea worms of the Xenoturbella genus (Israelsson 2007; Kjeldsen et al. 2010), as a component of sponge bacterial flora (Zhu et al. 2008) and as an element of the aquatic environment without a specific host (Thomas et al. 2006; Corsaro et al. 2009). It must be added that, among the previously known CLOs prevalent in the aquatic environment, such as Estrella lausannensis and Parachlamydia acanthamoebae, as well as Waddlia chondrophila isolated from cattle (Table 1), it was evidenced that they possess the ability to infect fish cell lines, whereas the greatest lesions in those cultures were caused by Waddlia chondrophila (Kebbi-Beghadadi et al. 2011). 
Table 1 Current taxonomy of the Chlamydiales order (Martel et al. 2012, 2013; Pawlikowska and Deptuła 2013; Vorimore et al. 2012; Sachse et al. 2014)

\begin{tabular}{|c|c|}
\hline Family I & Chlamydiaceae \\
\hline Genus & Chlamydia $(C)$. \\
\hline Species & C. trachomatis \\
\hline Species & C. suis \\
\hline Species & C. muridarum \\
\hline Species & C. psittaci \\
\hline Species & C. abortus \\
\hline Species & C. felis \\
\hline Species & C. caviae \\
\hline Species & C. pecorum \\
\hline Species & C. pneumoniae \\
\hline Species & C. ibidis \\
\hline Species & C. gallinacea \\
\hline Species & C. avium \\
\hline Species & Candidatus Amphibiichlamydia ranarum \\
\hline Species & Candidatus Amphibiichlamydia salamandrae \\
\hline Family II & Parachlamydiaceae \\
\hline Genus & Parachlamydia $(P)$. \\
\hline Species & P. acanthamoebae \\
\hline Genus & Neochlamydia $(N)$. \\
\hline Species & N. hartmannellae \\
\hline Genus & Protochlamydia $(P r)$. \\
\hline Species & Pr. amoebophila \\
\hline Species & Pr. neagreliophila \\
\hline Species & Candidatus Metachlamydia lacustris \\
\hline Family III & Simkaniaceae \\
\hline Genus & Simkania $(S)$. \\
\hline Species & S. negevensis \\
\hline Genus & Candidatus Fritschea \\
\hline Species & Candidatus Fritschea bemisiae \\
\hline Species & Candidatus Fritschea eriococci \\
\hline Family IV & Rhabdochlamydiaceae \\
\hline Genus & Rhabdochlamydia (R.) \\
\hline Species & R. porcellionis \\
\hline Species & R. crassificans \\
\hline Family V & Waddliaceae \\
\hline Genus & Waddlia $(W)$. \\
\hline Species & W. chondrophila \\
\hline Species & W. malaysiensis \\
\hline Family VI & Candidatus Piscichlamydiaceae \\
\hline Genus & Candidatus Piscichlamydia \\
\hline Species & Candidatus Piscichlamydia salmonis \\
\hline Family VII & Candidatus Clavichlamydiaceae \\
\hline Genus & Candidatus Clavichlamydia \\
\hline Species & Candidatus Clavichlamydia salmonicola \\
\hline Family VIII & Criblamydiaceae \\
\hline Genus & Criblamydia \\
\hline Species & Criblamydia sequanensis \\
\hline Species & Estrella lausannensis \\
\hline
\end{tabular}

These specific and characteristic lesions, specified as epitheliocystis in fish, were recorded for the first time among carps (Cyprinus carpio L.) in 1920, although the name occurred in the 1960s in reference to gill cysts described in bluegill (Lepomis macrochirus) (Hoffman et al. 1969). In many cases, epitheliocystis in fish have a mild form, but can also be manifested by such lesions as hypertrophy and infections of epithelial tissues and fish growth inhibition (Lewis et al. 1992; Crespo et al. 1999). Also described were cases where these changes could spread to other tissues of fish, such as gill lamellae, causing respiratory disorders and death of fish (Meijer et al. 2006; Draghi et al. 2007). It was also described that, in fish populations with a high mortality rate (even up to $100 \%$ ), those lesions can be manifested with exophthalmoses and lens prolapse, opacity of the cornea and blindness, as well as skin ulcers and backbone abnormality (Syasina et al. 2004). Typical lesions in the form of epitheliocystis as a result of CLOs infection have been described in farmed fish, including barramundi (Lates calcarifer) (Stride et al. 2013c), white sturgeon (Acipenser transmontanus) (Groff et al. 1996), silver perch (Bidyanus bidyanus) (Frances et al. 1997), Atlantic salmon (Salmo salar) (Nylund et al. 1998), red seabream (Pagrus major) (Syasina et al. 2004), carp (Cyprinus carpio) (Kim et al. 2005; Nowak and LaPatra 2006) and yellowtail amberjack (Seriola lalandi) (Mansell et al. 2005). Also, in bluestripe snapper (Lutjanus kasmira), the newly described CLO was identified, Candidatus Renichlamydia lutjani (Table 2), causing cysts in the kidneys and spleen, but not causing them in gills (Work et al. 2003). Moreover, in farmed salmon (Salmo salar), it was evidenced that aetiological factors for epitheliocystis are betaproteobacteria Candidatus Branchiomonas cysticola (Toenshoff et al. 2012) and Tenacibaculum maritimum (Rodger et al. 2011). Also, aetiological factors of epitheliocystis are CLOs known also as epitheliocyst-like organisms (ELOs), not assigned into families, which are characterised with a typical developmental cycle of Chlamydiales (Rockey and Matsumoto 2000). They have been identified in epitheliocystis in, among others, white sturgeon (Acipenser transmontanus) (Groff et al. 1996), red seabream (Spartus aurata) (Crespo et al. 1999), carp (Cyprinus carpio) (Kim et al. 2005), sharpsnout seabream (Diplodus puntazzo) (Katharios et al. 2008), leopard shark (Triakis semifasciata) (Polkinghorne et al. 2010) and spotted eagle ray (Aetobatus narinari) (Camus et al. 2013).

\section{CLOs infecting fish}

So far, two bacteria (Candidatus Piscichlamydia salmonis and Candidatus Clavichlamydia salmonicola) from the Chlamydiales order (Table 1) have been described, which cause pathogenic lesions in fish. At present, nine new pathogenic CLOs to fish have been identified, causing lesions in the 
Table 2 Chlamydiales pathogenic to fish (Draghi et al. 2004, 2007; Meijer et al. 2006; Karlsen et al. 2008; Polkinghorne et al. 2010; Corsaro and Work 2012; Kumar et al. 2012; Camus et al. 2013; Fehr et al. 2013; Pawlikowska and Deptuła 2013; Stride et al. 2013a, b, c; Steigen et al. 2013, 2015; Nylund et al. 2015)

\begin{tabular}{|c|c|}
\hline Family I & Chlamydiaceae \\
\hline \multirow[t]{2}{*}{ Family II } & Parachlamydiaceae \\
\hline & CRG18 \\
\hline Family III & Simkaniaceae \\
\hline Species & Candidatus Syngnamydia venezia \\
\hline Species & Candidatus Syngnamydia salmonis \\
\hline Family IV & Rhabdochlamydiaceae \\
\hline \multirow[t]{2}{*}{ Species } & Candidatus Renichlamydia lutjani \\
\hline & CRG20 \\
\hline Family V & Waddliaceae \\
\hline Family VI & Candidatus Piscichlamydiaceae \\
\hline Genus & Candidatus Piscichlamydia \\
\hline Species & Candidatus Piscichlamydia salmonis \\
\hline Species & Candidatus Piscichlamydia cyprinis \\
\hline Family VII & Candidatus Clavichlamydiaceae \\
\hline Genus & Candidatus Clavichlamydia \\
\hline Species & Candidatus Clavichlamydia salmonicola \\
\hline Family VIII & Criblamydiaceae \\
\hline Family IX & Candidatus Actinochlamydiaceae \\
\hline Species & Candidatus Actinochlamydia clariae \\
\hline Family X & Candidatus Parilichlamydiaceae \\
\hline Species & Candidatus Parilichlamydia carangidicola \\
\hline Species & Candidatus Similichlamydia latridicola \\
\hline Species & Candidatus Similichlamydia laticola \\
\hline Species & Candidatus Similichlamydia labri \\
\hline \multirow[t]{5}{*}{ Family incerta sedis } & UFC1 \\
\hline & UGA1 \\
\hline & WB13 \\
\hline & WB258 \\
\hline & CRG98 \\
\hline
\end{tabular}

form of gill epitheliocystis. It should be stated that the CLOs which are reported first as a cause of specific cysts in fish was the aforementioned Candidatus Piscichlamydia salmonis from the Candidatus Piscichlamydiaceae family (Table 1), isolated from farmed Atlantic salmon (Salmo salar) (Draghi et al. 2004). At present, it has been evidenced that the bacteria are characterised with a typical developmental cycle of Chlamydiales with three forms [elementary body (EB), reticular body (RB) and intermediate body (IB)], while their genetic similarity to the bacteria from the Parachlamydiaceae family amounts to $81-82 \%$ and $80 \%$ to the bacteria from the Chlamydia genus (Table 1) (Draghi et al. 2004). Apart from Atlantic salmon, these bacterium have also been identified in gill cysts in farmed Arctic charr (Salvelinus alpinus) in the USA and Canada (Draghi et al. 2010) and in wild brown trout (Salmo trutta) in Swiss rivers (Schmidt-Postahaus et al.
2012), whereas in gill epitheliocystis of those fishes, genetical material of Candidatus Clavichlamydia salmonicola from the Candidatus Clavichlamydiaceae family was found (Table 1) (Schmidt-Postahaus et al. 2012).

Another previously known bacterium causing gill cysts is the aforementioned Candidatus Clavichlamydia salmonicola from the Candidatus Clavichlamydiaceae family (Table 1), isolated from gill cysts of Norwegian salmon and from gills of Atlantic salmon farmed in Ireland, as well as from wild salmon where gill cysts and symptoms from the respiratory system were recorded (Karlsen et al. 2008). The studies based on their $16 \mathrm{~S}$ rRNA gene showed over $90 \%$ similarity to the bacteria from the Chlamydiales order, while phylogenetic analysis placed them in the Chlamydiaceae family and ECLVII (environmental chlamydial lineage) (Table 1) (Karlsen et al. 2008). Despite those facts, the revealed similarity between Candidatus Clavichlamydia salmonicola and Candidatus Piscichlamydia salmonis, at the level of $81 \%$, those bacteria formed a new family, Candidatus Clavichlamydiaceae, within the Chlamydiales order (Table 2) (Karlsen et al. 2008).

The next bacterium among Chlamydiales, presently described, which causes pathogenic lesions in fish is Candidatus Actinochlamydia clariae (Table 2). This bacterium was detected in gill epitheliocystis in juvenile forms of the African sharptooth catfish (Clarias gariepinus), farmed in Uganda (Steigen et al. 2013), where respiratory symptoms and a high mortality rate were recorded. In histopathological studies, in fishes' gills, hyperplasia of infected cells was detected, with inclusions inside surrounded with a double membrane. Furthermore, in the infected cell structure, apart from the shifting of cellular organelle to the sides, tunnels and tubular structures have been observed, radially stretching from the inclusion membrane, probably built of protein (Steigen et al. 2013). The forms were compared to actin which gives shape to the cell, and - as in this case - allows for opening the cellular membrane and entry into the cytosol of the neighbouring cell (Steigen et al. 2013). In these bacterium, three morphological forms in their developmental cycle were also found, namely EB, RB and IB. Phylogenetic analysis based on the obtained partial sequence of the 16S rRNA gene of those bacteria, compared to analogical sequences of the representatives of all eight families from the Chlamydiales order (Table 1), revealed similarity from $80.5 \%$ to $86.3 \%$, whereas the highest similarity was recorded between the sequence obtained and Candidatus Piscichlamydia salmonis, although morphologically, two such bacteria are not similar. Hence, on the basis of phylogenetic studies, considering the criteria proposed by Everett et al. (1999), establishment of a new, ninth Actinochlamydiaceae family was declared in the Chlamydiales order (Table 2) (Steigen et al. 2013).

Another CLO pathogenic to fish is Candidatus Parilichlamydia carangidicola (Table 2), isolated from gill 
cysts of yellowtail amberjack (Seriola lalandi) living near the South Australian coast (Stride et al. 2013a). Microscopic analyses of fishes' gills revealed elongated RBs, spherical IBs and no EBs in their cysts. Genetic analysis on the basis of a fragment of $16 \mathrm{~S}$ rRNA revealed $87 \%$ similarity to the analogical sequence of Candidatus Piscichlamydia salmonis, hence the name for the species, Candidatus Parilichlamydia carangidicola, was proposed, as well as the name for the new, tenth family within the Chlamydiales order: Candidatus Parilichlamydiaceae (Table 2) (Stride et al. 2013a).

Another currently described factor causing epithelial cysts in fish is Candidatus Similichlamydia latridicola (Table 2), found in gill epithelial cysts in striped trumpeter (Latris lineata) (Stride et al. 2013b). Molecular studies on this bacterium on the basis of the $16 \mathrm{~S}$ rRNA gene revealed a similarity at the level of $93.7-94 \%$ to the sequence of the Candidatus Parilichlamydia carangidicola taxon, and $88 \%$ similarity to Candidatus Piscichlamydia salmonis. In turn, phylogenetic analysis revealed that taxons (Candidatus Similichlamydia latridicola, Candidatus Parilichlamydia carangidicola) form a separate clad; hence, on the basis of the criteria proposed by Everett et al. (1999), it was considered justified to establish a separate, eleventh new family Candidatus Parilichlamydiaceae within the Chlamydiales order (Table 2).

The other new species is Candidatus Similichlamydia laticola (Table 2), which, similarly to Candidatus Similichlamydia latridicola, was isolated from epithelial cysts in farmed barramundi (Lates calcarifer) in Australia, in various developmental stadium, starting from eggs before hatching, through individuals aged 514 days (Stride et al. 2013c). Histopathological studies revealed that gill cysts in fish are located in gill lamellae, both at the base and at the centre and the edge, are basophil and surrounded with a membrane. In the in situ hybridisation test using specific probes for the Chlamydiales order for the 16S rRNA gene, the bacterium responds positively, while phylogenetic analysis revealed that the sequences obtained from all individuals analysed yielded 97.1-97.5\% similarity to the analogical sequence of Candidatus Similichlamydia latridicola from the Candidatus Parilichlamydiaceae family (Table 2).

Another described factor in the Chlamydiales order causing diseases among fish is Candidatus Similichlamydia labri, identified in gill epithelial cysts in ballan wrasse (Labrus bergylta) in Norway (Steigen et al. 2015), which featured RBs, IBs and EBs. Morphologically, cysts and inclusions with those bacteria resembled the same forms observed for Candidatus Actinochlamydia clariae, although actin, characterised for the aforementioned bacterium, was not found here. Genetic studies on the basis of the 16S rRNA sequence revealed $97.1 \%$ similarity to Candidatus Similichlamydia latridicola, $94.9 \%$ similarity to Candidatus Actinochlamydia clariae and $93.3 \%$ similarity to Candidatus Parilichlamydia latridicola. According to the postulates by
Everett et al. (1999), it was assigned to the Candidatus Parilichlamydiaceae family (Table 2).

The next, also recently described bacterium among CLOs pathogenic to fish is Candidatus Syngnamydia venezia (Table 2), isolated from gill cysts of broadnosed pipefish (Syngnathus typhle), living in the Venice lagoon (Fehr et al. 2013). The cysts were oval in shape and anchored in gill lamellae, while the histological study revealed intracellular granular material with bacteria sized $1-2 \mu \mathrm{m}$. Their allocation to the Chlamydiales order was checked using the fluorescence in situ hybridisation (FISH) method with Chls-523 marker. In turn, molecular analysis of their material, based on the $16 \mathrm{~S}$ rRNA gene, revealed the highest similarity to the analogical sequence of an unnamed isolate obtained from Xenoturbella westbladi (96\%) and to Fritschea eriococci (94\%) and Fritschea bemisiae (94\%), as well as Simkania negevensis (93\%) from the Simkaniaceae family (Table 1). Therefore, it was proposed to establish a new genus in the Simkaniaceae family, namely Candidatus Syngnamydia venezia (Table 2), a species which is characterised with the lack of two-phase developmental cycle, as no EBs were observed in them, or other infectious forms, but exclusively RB bodies, which are probably capable of initiating the infection (Fehr et al. 2013).

Another described CLO pathogenic to fish is Candidatus Syngnamydia salmonis (Table 2), identified in gill cysts of Atlantic salmon (Salmo salar L.) farmed in Norway, which recorded a high mortality rate (Nylund et al. 2015). Using an electron microscope, cysts of those fish were found to contain bacteria with a different appearance than previously observed, surrounded with a double membrane. The forms were large, elongated (up to $2.5 \mu \mathrm{m}$ long) and contained granular (ribosomes) and amorphous material (chromatin), which was deemed to be RBs). In turn, the described smaller rod-shaped forms $(0.7-1.0 \times 0.4-0.5 \mu \mathrm{m})$, with peak disc (cap) and a semi-transparent zone similar to vacuoles underneath, was recognised as EBs. Also, forms sized 500-800 nm were observed, namely IBs. Genetic analysis of $16 \mathrm{~S}$ rRNA in those bacteria revealed that, in over $90 \%$ (91.7-98.1\%), it conforms to analogical sequences of the representatives of the Simkaniaceae family (Table 1), whereas the highest similarity was recorded in the case of symbiont Xenoturbella westbladi (98.1\%) and Candidatus Syngnamydia venezia (95.7\%), as well as Fritschea eriococci (94.5\%), Fritschea bemisiae (94.3\%) and Simkania negevensis (91.7\%). Therefore, on the basis of the obtained results, it was determined that the bacterium is grouped together with the still unnamed isolate (SM081012-5S) obtained from corkwing wrasse (Symphodus melops) and with the isolate from Xenoturbella westbladi, in the Simkaniaceae family (Table 2) (Nylund et al. 2015).

The other new species is Candidatus Renichlamydia lutjani (Table 2), which was observed in bluestripe snapper (Lutjanus kasmira) (Corsaro and Work 2012). This bacterium was found in the kidneys and spleen of those fish, in inclusions 
resembling epitheliocystis containing Gram-negative bacteria and stained positive using the Gimenez method. Genetical analysis revealed that 300 -bp sequence bp of $16 \mathrm{~S}$ rRNA is in $88.2-88.7 \%$, similar to the analogical sequence of the representatives of the Rhabdochlamydiaceae family; thus, the bacterium was assigned to this family (Table 2), although it is also $85-86.7 \%$ identical to the representatives of the Simkaniaceae family (Table 1) (Corsaro and Work 2012).

Another described CLO is Candidatus Piscichlamydia cyprinis (Table 2), identified in gill cysts of farmed grass carp (Ctenopharyngodon idella), suffering symptoms of the respiratory system (Kumar et al. 2012). In those fish, cysts were placed at the base of gill lamellae, and were filled with granular basophilic material. Genetical analysis of a fragment of the $16 \mathrm{~S}$ rRNA gene revealed $96 \%$ similarity to the analogical sequence of Candidatus Piscichlamydia salmonis, which may point to the fact that both species belong to the Candidatus Piscichlamydiaceae family (Table 2).

Another group of CLOs causing pathogenic lesions in fish, also named as ELOs, are bacteria not assigned into families in the Chlamydiales order. Those bacteria were observed in white sturgeon (Groff et al. 1996), in gill cysts of which bacteria with three developmental forms (EB, RB and IB) were found, while serological tests proved positive for chlamydial lipopolysaccharide (LPS). Analogical observations using microscope analysis and reactions with chlamydial LPS carried out on gill cysts in red seabream (Spartus aurata) farmed near the Spanish coast (Crespo et al. 1999), as well as carp (Cyprinus carpio) in South Korea (Kim et al. 2005), also pointed to three forms specific to Chlamydiales in lesions, as a result of which those bacteria were classified as CLOs. Similar observations were made in Crete in the larvae of farmed sharpsnout seabream (Diplodus puntazzo), among which a high mortality rate was recorded (Katharios et al. 2008) and which had lesions in the form of cysts located principally within the primary fin, skin epithelium and rostrum. Histological studies inside the cysts pointed to the presence of particles determined to be elementary and reticulate bodies, characteristic of Chlamydiales, although no cellular response was recorded in them, including cell hypertrophy in the infected tissues (Katharios et al. 2008).

Also in osteochondral fish, such as leopard shark (Triakis semifasciata) (Polkinghorne et al. 2010) and spotted eagle ray (Aetobatus narinari) (Camus et al. 2013), chlamydia-like factors of epitheliocystis were described. In the case of leopard shark, the UFC1 isolate was described (Table 2), the genetic analysis of which revealed $89 \%$ affinity to the representatives of the Chlamydiales order, although it created a separate line in this order (Polkinghorne et al. 2010). In serological studies, the UFC1 isolate did not reveal a positive reaction with chlamydial LPS, while in histopathological studies, it was pointed out that it causes macrophage infiltration in gill epithelial cells, which were in the majority of necrotic cells (Polkinghorne et al. 2010). In turn, in spotted eagle ray, the UGA1 isolate was analysed (Table 2), characterised with the fact of inclusions featuring a uniform pool of elongated cells, with the lack of positive reaction with anti-chlamydial antibodies, whereas genetic analysis of $16 \mathrm{~S}$ rRNA pointed to $85-89 \%$ similarity to Candidatus Piscichlamydia salmonis (Camus et al. 2013). Also, while analysing epithelial cysts of Arctic charr (Salvelinus alpinus), bacteria were found, marked as isolates WB13 and WB258 (Table 2), revealing 97-100\% similarity to isolates from the Neochlamydia genus (Table 1) (Draghi et al. 2007). The same team (Draghi et al. 2010), while analysing Arctic charr (Salvelinus alpinus), apart from identification of the aforementioned Candidatus Piscichlamydia salmonis (Table 2) in the material sampled from the cysts, also detected a chlamydia-like sequence (GenBank accession number FJ168566) revealing over $80 \%$ similarity to the analogical sequence (16S rRNA) of the representatives of the Chlamydiales order with simultaneous similarity to known chlamydia-like sequences remaining below $92 \%$. Also, in epithelial cysts from gills of leafy seadragon (Phycodurus eques) (CRG20), silver perch (Bidyanus bidyanus) (CRG18) and in cysts from gills and skin of barramundi (Lates calcarifer) (CRG98), bacteria were observed, the phylogenetic analysis of which evidenced that they belong to families in the Chlamydiales order and are grouped as follows, respectively: CRG20 with $R$. porcellion is in the Rhabdochlamydiaceae family, CRG18 with endosymbionts of amoebas TUME1 and UWC22 in the Parachlamydiaceae family, while CRG98 forms a separate line between lines with Piscichlamydia salmonis and $R$. porcellionis (Meijer et al. 2006).

\section{Conclusion}

The presented data indicate that, at present, 11 chlamydia-like organisms (CLOs) pathogenic to fish are known, including nine newly identified, classified into six families (Parachlamydiaceae, Rhabdochlamydiaceae, Candidatus Parilichlamydiaceae, Candidatus Clavichlamydiaceae, Candidatus Actinochlamydiaceae and Candidatus Parilichlamydiaceae), principally on the basis of genetic studies. A common characteristic of those bacteria is the fact of infecting epithelial cells of fishes, prevalence of developmental forms typical of Chlamydiales and causing an immune response in the form of macrophage infiltrations, as well as impossibility of their in vitro cultivation. It must be added that it was experimentally evidenced that epithelial cells in fish are also sensitive to infection with CLOs and causing immune response, such as Waddlia chondrophila and Parachlamydia acanthamoebae, as well as Estrella lausannensis, which may constitute a basis for analogical studies, including immunological studies, related to bacteria causing epitheliocystis. 
Such facts evidence that, despite Chlamydiales being known for hundreds of years, there is a continuous need for monitoring them, as currently presented CLOs forms are generally prevalent bacteria in the aquatic environment, which pose a real threat to the life and health of fish, and indirectly possibly also to the health of mammals, including humans.

Open Access This article is distributed under the terms of the Creative Commons Attribution 4.0 International License (http:// creativecommons.org/licenses/by/4.0/), which permits unrestricted use, distribution, and reproduction in any medium, provided you give appropriate credit to the original author(s) and the source, provide a link to the Creative Commons license, and indicate if changes were made.

\section{References}

Camus A, Soto E, Berliner A, Clauss T, Sanchez S (2013) Epitheliocystis hyperinfection in captive spotted eagle rays Aetobatus narinari associated with a novel Chlamydiales $16 \mathrm{~S}$ rDNA signature sequence. Dis Aquat Organ 104:13-21

Corsaro D, Venditti D (2009) Detection of Chlamydiae from freshwater environments by PCR, amoeba coculture and mixed coculture. Res Microbiol 160:547-552

Corsaro D, Work TM (2012) Candidatus Renichlamydia lutjani, a Gramnegative bacterium in internal organs of blue-striped snapper Lutjanus kasmira from Hawaii. Dis Aquat Org 98:249-254

Corsaro D, Feroldi V, Saucedo G, Ribas F, Loret J-F, Greub G (2009) Novel Chlamydiales strains isolated from a water treatment plant. Environ Microbiol 11:188-200

Crespo S, Zarza C, Padros F, Marin de Mateo M (1999) Epitheliocystis agents in sea bream Sparus aurata: morphological evidence for two distinct Chlamydia-like developmental cycles. Dis Aquat Organ 37: $61-72$

Dallaire-Dufresne S, Tanak KH, Trudel MV, Lafaille A, Charette SJ (2014) Virulence, genomic features, and plasticity of Aeromonas salmonicida subsp. salmonicida, the causative agent of fish furunculosis. Vet Microbiol 169:1-7

Draghi A II, Popov VL, Kahl MM, Stanton JB, Brown CC, Tsongalis GJ, West AB, Frasca S Jr (2004) Characterization of "Candidatus Piscichlamydia salmonis" (order Chlamydiales), a chlamydia-like bacterium associated with epitheliocystis in farmed Atlantic salmon (Salmo salar). J Clin Microbiol 42:5286-5297

Draghi A II, Bebak J, Popov VL, Noble AC, Geary SJ, West A, Byrne P, Frasca S Jr (2007) Characterization of a Neochlamydia-like bacterium associated with epitheliocystis in cultured Arctic charr Salvelinus alpinus. Dis Aquat Organ 76:27-38

Draghi A II, Bebak J, Daniels S, Tulman ER, Geary SJ, West AB, Popov VL, Frasca S Jr (2010) Identification of 'Candidatus Piscichlamydia salmonis' in Arctic charr Salvelinus alpinus during a survey of charr production facilities in North America. Dis Aquat Org 89:39-49

Everett KD, Bush RM, Andersen AA (1999) Emended description of the order Chlamydiales, proposal of Parachlamydiaceae fam. nov. and Simkaniaceae fam. nov., each containing one monotypic genus, revised taxonomy of the family Chlamydiaceae, including a new genus and five new species, and standards for the identification of organisms. Int J Syst Bacteriol 49:415-440

Fehr A, Walther E, Schmidt-Posthaus H, Nufer L, Wilson A, Svercel M, Richter D, Segner H, Pospischil A, Vaughan L (2013) Candidatus Syngnamydia venezia, a novel member of the phylum Chlamydiae from the broad nosed pipefish, Syngnathus typhle. PLoS One 8: e70853
Frances J, Tennent R, Nowak BF (1997) Epitheliocystis in silver perch, Bidyanus bidyanus (Mitchell). J Fish Dis 20:453-457

Groff JM, LaPatra SE, Munn RJ, Anderson ML, Osburn BI (1996) Epitheliocystis infection in cultured white sturgeon (Acipenser transmontanus): antigenic and ultrastructural similarities of the causative agent to the chlamydiae. J Vet Diagn Invest 8:172-180

Haenen OLM, Evans JJ, Berthe F (2013) Bacterial infections from aquatic species: potential for and prevention of contact zoonoses. Rev Sci Tech Int Off Epiz 32:497-507

Hoffman GL, Dunbar CE, Wolf K, Zwillenberg LO (1969) Epitheliocystis, a new infectious disease of the bluegill (Lepomis macrochirus). Antonie van Leeuwenhoek J Microbiol Serol 35: $146-158$

Israelsson O (2007) Chlamydial symbionts in the enigmatic Xenoturbella (Deuterostomia). J Invertebr Pathol 96:213-220

Joh S-J, Ahn E-H, Lee H-J, Shin G-W, Kwon J-H, Park C-G (2013) Bacterial pathogens and flora isolated from farm-cultured eels (Anguilla japonica) and their environmental waters in Korean eel farms. Vet Microbiol 163:190-195

Karlsbakk E, Olsen AB, Einen A-CB, Mo TA, Fiksdal IU, Aase H, Kalgraff C, Skar S-A, Hansen H (2013) Amoebic gill disease due to Paramoeba perurans in ballan wrasse (Labrus bergylta). Aquaculture 412-413:41-44

Karlsen M, Nylund A, Watanabe K, Helvik JV, Nylund S, Plarre H (2008) Characterization of 'Candidatus Clavochlamydia salmonicola': an intracellular bacterium infecting salmonid fish. Environ Microbiol 10:208-218

Katharios P, Papadaki M, Papandroulakis N, Divanach P (2008) Severe mortality in mesocosm-reared sharpsnout sea bream Diplodus puntazzo larvae due to epitheliocystis infection. Dis Aquat Org 82: $55-60$

Kebbi-Beghadadi C, Batista C, Greub G (2011) Permissivity of fish cell lines to three Chlamydia-related bacteria: Waddlia chondrophila, Estrella lausannensis and Parachlamydia acanthamoebae. FEMS Immunol Med Microbiol 63:339-345

Kim D-J, Park J-H, Seok S-H, Cho S-A, Baek M-W, Lee H-Y, Park J-H (2005) Epitheliocystis in carp (Cyprinus carpio) in South Korea. J Vet Med Sci 67:119-120

Kjeldsen KU, Obst M, Nakano H, Funch P, Schramm A (2010) Two types of endosymbiotic bacteria in the enigmatic marine worm Xenoturbella bocki. Appl Environ Microbiol 76:2657-2662

Kumar G, Mayrhofer R, Soliman H, El-Matbouli M (2012) Novel Chlamydiales associated with epitheliocystis in grass carp (Ctenopharyngodon idella). Vet Rec. doi:10.1136/vr.101193

Lewis EJ, McLaughlin SM, Bodammer JE, Sawyer TK (1992) Epitheliocystis in ten new host species of marine fish. J Fish Dis 15:267-271

Mansell B, Powell MD, Ernst I, Nowak BF (2005) Effects of the gill monogenean Zeuxapta seriolae (Meserve, 1938) and treatment with hydrogen peroxide on pathophysiology of kingfish, Seriola lalandi Valenciennes, 1833. J Fish Dis 28:253-262

Martel A, Adriaensen C, Bogaerts S, Ducatelle R, Favoreel H, Crameri S, Hyatt AD, Haesebrouck F, Pasmans F (2012) Novel Chlamydiaceae disease in captive salamanders. Emerg Infect Dis 18:1020-1022

Martel A, Adriaensen C, Sharifian-Fard M, Vandewoestyne M, Deforce D, Favoreel H, Bergen K, Spitzen-van der Sluijs A, Devisscher S, Adriaens T, Louette G, Baert K, Hyatt A, Crameri S, Haesebrouck F, Pasmans F (2013) The novel 'Candidatus Amphibiichlamydia ranarum' is highly prevalent in invasive exotic bullfrogs (Lithobates catesbeianus). Environ Microbiol Rep 5:105-108

Meijer A, Roholl PJM, Ossewaarde JM, Jones B, Nowak BF (2006) Molecular evidence for association of Chlamydiales bacteria with epitheliocystis in leafy seadragon (Phycodurus eques), silver perch (Bidyanus bidyanus), and barramundi (Lates calcarifer). Appl Environ Microbiol 72:284-290 
Mitchell SO, Rodger HD (2011) A review of infectious gill disease in marine salmonid fish. J Fish Dis 34:411-432

Nowak BF, LaPatra SE (2006) Epitheliocystis in fish. J Fish Dis 29:573588

Nylund A, Kvenseth AM, Isdal E (1998) A morphological study of the epitheliocystis agent in farmed Atlantic salmon. J Aquat Anim Health 10:43-55

Nylund S, Steigen A, Karlsbakk E, Plarre H, Andersen L, Karlsen M, Watanabe K, Nylund A (2015) Characterization of 'Candidatus Syngnamydia salmonis' (Chlamydiales, Simkaniaceae), a bacterium associated with epitheliocystis in Atlantic salmon (Salmo salar L.). Arch Microbiol 197:17-25. doi:10.1007/s00203-014-1038-3

Pawlikowska M, Deptuła W (2013) Characteristics of the Chlamydia of the family Chlamydiaceae that are pathogenic to humans and animals (in Polish). Med Weter 69:649-654

Pierce LR, Stepien CA (2012) Evolution and biogeography of an emerging quasispecies: diversity patterns of the fish Viral Hemorrhagic Septicemia virus (VHSv). Mol Phylogenet Evol 63:327-341

Polkinghorne A, Schmidt-Posthaus H, Meijer A, Lehner A, Vaughan L (2010) Novel Chlamydiales associated with epitheliocystis in a leopard shark Triakis semifasciata. Dis Aquat Organ 91:75-81

Rockey DD, Matsumoto A (2000) The chlamydial developmental cycle. In: Brun YV, Shimkets LJ (eds) Prokaryotic development. American Society of Microbiology Press, Washington, pp 403-410

Rodger HD, Murphy K, Mitchell SO, Henry L (2011) Gill disease in marine farmed Atlantic salmon at four farms in Ireland. Vet Rec. doi:10.1136/vr.d3020

Rodriguez-Tovar LE, Speare DJ, Markham RJF (2011) Fish microsporidia: Immune response, immunomodulation and vaccination. Fish Shellfish Immunol 30:999-1006

Sachse K, Laroucau K, Riege K, Wehner S, Dilcher M, Creasy HH, Weidmann M, Myers G, Vorimoe F, Vicari N, Magnino S, LieblerTenorio E, Ruettger A, Bavoil PM, Hufert FT, Rosselló-Móra R, Marz M (2014) Evidence for the existence of two new members of the family Chlamydiaceae and proposal of Chlamydia avium sp. nov. and Chlamydia gallinacea sp. nov. Syst Appl Microbiol 37:79-88

Samad APA, Santoso U, Lee M-C, Nan F-H (2014) Effects of dietary katuk (Sauropus androgynus L. Merr.) on growth, non-specific immune and diseases resistance against Vibrio alginolyticus infection in grouper Epinephelus coioides. Fish Shellfish Immunol 36:582589

Schmidt-Postahaus H, Polkinghorne A, Nufer L, Schifferli A, Zimmermann DR, Segner H, Steiner P, Vaughan L (2012) A natural freshwater origin for two chlamydial species, Candidatus Piscichlamydia salmonis and Candidatus Clavochlamydia salmonicola, causing mixed infections in wild brown trout (Salmo trutta). Environ Microbiol 14:2048-2057

Steckler NK, Yanomng RP, Pouder DB, Nyaoke A, Sutton DA, Lindner JR, Wickes BL, Frasca S Jr, Wolf JC, Waltzek TB (2014) New disease records for hatchery-reared sturgeon. II. Phaeohyphomycosis due to Veronaea botryosa. Dis Aquat Dis 111:229-238

Steigen A, Nylund A, Karlsbakk E, Akoll E, Fiksdal IU, Nylund S, Odong R, Heidrun P, Semaylo R, Skår C, Watanabe K (2013) 'Cand. Actinochlamydia clariae' gen. nov., sp. nov., a unique intracellular bacterium causing epitheliocystis in catfish (Clarias gariepinus) in Uganda. PLoS One 8:e66840

Steigen A, Karlsbakk E, Plarre H, Watanabe K, Øvergård A-C, Brevik Ø, Nylund A (2015) A new intracellular bacterium, Candidatus
Similichlamydia labri sp. nov. (Chlamydiaceae) producing epitheliocysts in ballan wrasse, Labrus bergylta (Pisces, Labridae). Arch Microbiol 197:311-318. doi:10.1007/s00203-014-1061-4

Steinum T, Kvellestad A, Colquhoun DJ, Heum M, Mohammad S, Nygaard Grøntvedt R, Falk K (2010) Microbial and pathological findings in farmed Atlantic salmon Salmo salar with proliferative gill inflammation. Dis Aquat Org 91:201-211

Stride MC, Polkinghorne A, Miller TL, Groff JM, LaPatra SE, Nowak BF (2013a) Molecular characterization of "Candidatus Parilichlamydia carangidicola," a novel Chlamydia-like epitheliocystis agent in yellowtail kingfish, Seriola lalandi (Valenciennes), and the proposal of a new family, "Candidatus Parilichlamydiaceae" fam. nov. (order Chlamydiales). Appl Environ Microbiol 79:1590-1597

Stride MC, Polkinghorne A, Miller TL, Nowak BF (2013b) Molecular characterization of "Candidatus Similichlamydia latridicola" gen. nov., sp. nov. (Chlamydiales: "Candidatus Parilichlamydiaceae"), a novel Chlamydia-like epitheliocystis agent in the striped trumpeter, Latris lineata (Forster). Appl Environ Microbiol 79:4914-4920

Stride MC, Polkinghorne A, Powell MD, Nowak BF (2013c) "Candidatus Similichlamydia laticola", a novel chlamydia-like agent of epitheliocystis in seven consecutive cohorts of farmed Australian barramundi, Lates calcarifer (Bloch). PLoS One 8: e82889. doi:10.1371/journal.pone.0082889

Stride MC, Polkinghorne A, Nowak BF (2014) Chlamydial infections of fish: diverse pathogens and emerging causes of disease in aquaculture species. Vet Microbiol 170:19-27

Syasina I, Park I-S, Kim JM (2004) Epitheliocystis disease in red sea bream Pagrus major and induced hybrid, red sea bream Pagrus major (female) $\times$ black sea bream Acanthopagrus schlegeli (male), cultured in Korea. Bull Eur Ass Fish Pathol 24:260-267

Thomas V, Casson N, Greub G (2006) Criblamydia sequanensis, a new intracellular Chlamydiales isolated from Seine river water using amoebal co-culture. Environ Microbiol 8:2125-2135

Toenshoff ER, Kvellestad A, Mitchell SO, Steinum T, Falk K, Colquhoun DJ, Horn M (2012) A novel betaproteobacterial agent of gill epitheliocystis in seawater farmed Atlantic salmon (Salmo salar). PLoS One 7:e32696. doi:10.1371/journal.pone.0032696

Vorimore F, Hsia R-C, Huot-Creasy H, Bastian S, Deruyter L, Passet A, Sachse K, Bavoil P, Myers G, Laroucau K (2012) Isolation of a new Chlamydia species from the feral sacred ibis (Threskiornis aethiopicus): Chlamydia ibidis. PLoS One 8:e74823. doi:10.1371/ journal.pone. 0074823

Work TM, Rameyer RA, Takata G, Kent ML (2003) Protozoal and epitheliocystis-like infections in the introduced bluestripe snapper Lutjanus kasmira in Hawaii. Dis Aquat Org 57:59-66

Yu S, Feng J, Sun X, Jiang J, Zhixun G, Ye L, Xu L (2014) A new species of Glugea Thélohan, 1891 in the red sea bream Pagrus major (Temminck \& Schlegel) (Teleostei: Sparidae) from China. Syst Parasitol 89:175-183

Zamora L, Vela AI, Sánchez-Porro C, Palacios MA, Domínguez L, Moore ERB, Ventosa A, Fernández-Garayzábal JF (2013) Characterization of flavobacteria possibly associated with fish and fish farm environment. Description of three novel Flavobacterium species: Flavobacterium collinsii sp. nov., Flavobacterium branchiarum sp. nov., and Flavobacterium branchiicola sp. nov. Aquaculture 416-417:346-353

Zhu P, Li Q, Wang G (2008) Unique microbial signatures of the alien Hawaiian marine sponge Suberites zeteki. Microb Ecol 55:406-414 